\title{
Rediscovering other geographical traditions
}

\section{Federico Ferretti \\ federico.ferretti@ucd.ie}

\begin{abstract}
In the last few years, a vibrant interdisciplinary and international literature is rediscovering those sectors of the geographical tradition whose exponents did not match the classical stereotype of the Western academic geographer directly or indirectly contributing to colonialism, warfare and social conservatism. Ongoing research on primary sources has shown that early progressive, dissident and unorthodox tendencies in the history of the discipline were more pervasive and influential than what has been believed. In this paper, I define this movement as the rediscovery of 'Other Geographical Traditions' (OGTs) arguing that this notion can enlarge our understanding of geography as a plural and contested field. While a great deal of this literature is constituted by studies on early anarchist and critical geographies, I argue that this concept should be extended to scholarly production from the Global South in languages other than English, which is likewise providing important contributions to the discovery of different geographical traditions, politically and culturally. For that, I address the case of recent Latin American scholarship, in Spanish and Portuguese, on the history and philosophy of critical geographies. Moreover, the fact that these 'Southern' scholars are rereading and translating classical figures of 'Northern' geographers constitutes a reversal of the former colonial gaze from the North-South to the South-North direction. This suggest that the study of OGTs should also consider different cultural and linguistic traditions, challenging monolingualism in both literature reviews and sources' selection.
\end{abstract}

Keywords: Other geographical Traditions; Early Critical Geographies; Radical Historical Geographies; Anarchism; Latin America

This paper focuses upon the recent rediscovery of what I define as 'Other Geographical Traditions' (OGTs). I argue for a deeper understanding of this notion, in geography and those cognate disciplines interested in the circulation and production of scholarly ideas associated with critical thinking and activism. To this end, I draw upon recent geographical scholarship, especially that set up by Innes Keighren in addressing the increasing tendency to rediscover the 'admirable' sides of the geographical tradition, beyond classical works discussing geographers' collaboration with imperialism, warfare and totalitarianisms. For Keighren, 'while some phases of geography's disciplinary history, and some stripes of its philosophy, engender in us shame and demand our atonement, others have the capacity to inspire our admiration and to signal to future possibilities' (Keighren 2018, 775).

These remarks allude to the growing interest in early anarchist, critical and anti-colonial geographies that challenge traditional canons in disciplinary history. More generally, they can be applied to many of the 'hidden histories' (Driver 2012) which were excluded from classical readings of the histories of geography that were generally limited to texts by established European and North-American academics. Taking inspiration from these recent strands of literature, I would argue that geography is a discipline which has always attracted scholars willing to change the world, and that understanding the diversity of its histories is crucial to appreciate the potentiality of socially engaged geographies today. While geography's

F. Ferretti, 2019, "Rediscovering other geographical traditions", Geography Compass, https://onlinelibrary.wiley.com/doi/full/10.1111/gec3.12421 
'relevance' has been often highlighted with reference to its alternative traditions (Stoddart 1975; Kearns 2004), my definition of OGTs is broader, and substantially threefold.

First, it includes histories of the production of critical, radical, feminist, unorthodox and anarchist geographies before these definitions became canonised or even prevailing in geographical scholarship. This involves the production of knowledge considered as noncanonical or not fitting contemporary standards of professional geographies. For instance, some of the early inspirers of critical approaches to geography, such as Alexander von Humboldt (1769-1859), Elisée Reclus (1830-1905) and Pyotr Kropotkin (1842-1921), did not correspond to the present-day figure of the professional geographer as an established academic. This first definition also necessitates taking some precautions against anachronism. This is typically the case with anarchism, which I consider as the principal stream (but hardly the only one) in the rediscovery of OGTs as I explain in the next section. While anarchist geographies play a major role in the process described above by Keighren, a great part of the related scholarship focuses on authors like Reclus, Kropotkin and their fellows, who worked at a time when the definition of 'anarchist geographies' did not exist. Therefore, some scholars prefer to talk about 'anarchist geographers' rather than 'geographies' (Pelletier 2013; Siegrist 2017). Yet, recent literature admits retrospective uses of the definition 'anarchist geographies' to describe specific contents from early authors which anticipated notions debated today (Ferretti 2018a; Springer 2016). This matches current trends in the history of geography which counter positivistic readings of disciplinary history by noticing the cyclical coming back of 'old theories' under new forms which meet new scholarly and societal needs -- for instance biogeography or environmental determinism (Livingstone 2012; Cresswell 2013). In this first definition of OGTs, I include the history of the first rising of 'radical geographies' in the 1960s and 1970s, because this field has been the object of recent historical investigations and because, in these years, radical and critical scholars still had to challenge an established conservative mainstream.

Second, I include knowledge produced 'outside the bubble of the Global North' (Melgaço 2017) in this notion of OGTs. While geographies from the 'Global South', with all the necessary cautions about the use of this definition (Sparke 2007), are not necessarily politically progressive, they can doubtlessly be considered as a linguistic and cultural alternative to mainstream scholarly production. This is now generally identified as the Anglosphere, which exerts a planetary hegemony in publications, funding and scholarly production. Moreover, the strong critical drive of radical approaches from peripheral regions of the world is noteworthy: this is especially the case with Latin America, as I discuss below.

Third, I would suggest considering as a special case in OGTs the recent flourishing of histories of geographies produced in the South about Northern scholars, which can be considered as a way to reverse the traditional colonial gaze of the colonisers studying the colonised. This is again the case with recent Latin-American scholarship in Spanish and Portuguese discussing 'eminent' Northern scholars, to exert a re-appropriation of disciplinary histories from their standpoint. Studying this literature constitutes a challenge to the all-to-frequent English monolingualism in the literature reviews of papers published in international journals: it is no longer possible to claim for decolonising the discipline, for plurality and inclusiveness of the geographical communities if we continue to read only materials produced or translated in one language. This does not mean that I oppose the use of English as a scholarly lingua franca, an issue widely discussed in Critical Geographies fora (Desbiens and Ruddick 2006). What I

F. Ferretti, 2019, "Rediscovering other geographical traditions", Geography Compass, https://onlinelibrary.wiley.com/doi/full/10.1111/gec3.12421 
question is the unwillingness of several scholars to deal directly with sources produced in other codes and cultures, also considering that reception and translation studies show how slippery the notion of translation can be (Venuti 2000). For that, I will quote papers and books in Spanish, Portuguese and French, giving them the same importance as Anglophone titles. ${ }^{1}$

Therefore, I use OGTs as an encompassing definition. This implies that I do not propose any Manichean distinction between what OGTs are and what they are not. Yet, it is possible to establish some principle: for instance, works by scholars organically inserted in dominant paradigms of their day and/or serving political conservation could hardly match the definition of OGTs. Conversely, this encompasses forms of geographical knowledge which were variously ignored, marginalised or underplayed by the canons each time dominating the discipline, due to the positionality of their authors (e.g. political dissidents, women, nonacademic, non-White or non-Western persons) or to the unrecognized places and contexts in which these works were produced and disseminated (e.g. academically non-dominant languages, peripheral locations, non-academic outputs such as militant publications or works lacking the explicit label of 'geography'). As I explain below, identifying dominant canons is likewise a contentious matter and it would be odd trying to define them simply in opposition to OGTs. Moreover, considering as OGTs works which were not labelled as geography or lied at the margins of the discipline at a certain moment can further complicate these canons, emphasising the plural and networked nature of geographical traditions. The whole discipline will benefit from this enlargement of its frontiers to foster its inclusiveness, recently claimed by debates on decolonising the academy.

In the first part of my paper, I highlight examples of recent contributions on the diversity of geography's pasts and critical traditions between the eighteenth and the twentieth century, on reengaging with feminist historical geographies and on discovering early decolonial uses of maps. In the second part, I discuss the recent interest of disciplinary historiography in pioneering figures of the critical and radical turn of the 1960s and 1970s, both in the 'Global North' and in the 'Global South'. In the third part, I analyse the ongoing efforts of LatinAmerican historical geographers in reversing the direction of the classical colonial gaze from North to South by providing new readings of European or North American 'classics' in the history of geography. In this way, I wish to contribute to Keighren's claims for the importance of 'attempting to account for and give narrative shape to that diversity [as] both the challenge and the reward of scholarship on the history and philosophy of geography; the discipline rarely feels more vital than when contemplating its past ... to continue to remind ourselves of the good and the bad in who we are and in what we do, to see in our past both cause for regret and reason for hope' (Keighren 2018, 776). My goal is to demonstrate that geography and its pasts are not only tremendously vital, but tremendously diverse, and this diversity still deserves further work and recognition.

\section{Early critical geographies, feminist historical geographies and dissident mappings}

\subsection{Geography's diverse pasts}

The first and more spectacular case in the reconsideration of OGTs is that of anarchism, given that historical geographies of anarchism (Ferretti et al. 2017) and stories of early anarchist

\footnotetext{
${ }^{1}$ All quotes from texts in these languages have been translated by the author.
} 
geographers have undoubtedly played a key role in inspiring the idea that our discipline's pasts were more subversive than what has been believed. Anarchist geographies have seen a flourishing of publications in recent years, following the special issues on anarchism published by Antipode and ACME in 2012, and the study of the historical aspects of the relation between geography and anarchism is central to this strand of literature. This is well exemplified by books such as The Anarchist Roots of Geography by Simon Springer (2016) and the related book forum published by the AAG Review of Books (Sidaway 2017). Figures in early anarchist geography like Kropotkin have recently inspired research monographs by both geographers and non-geographers (Adams 2015; Ferretti 2018a; McLaughlin 2016; Kinna 2016). Crucially, one of the most important publications in the international field of anarchist geographies, the trilogy Anarchism, Geography and the Spirit of Revolt, edited by Springer, Richard White and Marcelo Lopes de Souza (2016), contains several historical contributions. Concurrently, figures like Reclus are increasingly discussed as forerunners of emerging anarchist tendencies on vegetarianism and veganism (White 2015). This emerging work allows arguing for the centrality of alternative, eventually anarchist, geographical traditions in this developing field of study.

An example of the importance of anarchism in inspiring works on different geography's pasts are geographies of anti-colonialism. Recent scholarship has rescued the neglected role of early anarchist geographers as European authors performing radical anti-colonialist and anti-racist agendas in imperial ages (Ferretti 2016 and 2017), extending interdisciplinary work on the 'transnational turn' in anarchist studies (Bantman and Altena 2015). Similar topics have been addressed by historical geographers working on geographies of radical histories from perspectives not strictly identifiable with the anarchist ones (Griffin 2018, Davies 2017; Featherstone 2017), and by a burgeoning literature on de-colonisation, Black internationalism and solidarity networks (Craggs and Wintle 2016; Hodder 2016, McGregor 2017). Therefore, OGTs are far from being limited to anarchism. First, because anarchism is a complex field which would hardly fit a unique scholarly 'paradigm', as exemplified by the discussions mentioned above about the definition of 'anarchist geographies'. Second, because other critical approaches (sometimes intersecting with anarchism) can contribute to the rediscovery of OGTs, such as Marxism and other socialistic tendencies, feminism, critical race studies, postcolonialism and decoloniality among the others.

This can be related to more general notions of unorthodoxy in the history of geography. For instance, Keighren analyses the case of the 'seditious knowledge' circulated by British traveller William Macintosh (ca. 1738-ca. 1816), who published a book on his Travels in Europe, Asia and Africa (1782) issued by famous publisher John Murray, which was the occasion for heated controversies and indignant replies. This was mainly because 'Macintosh was scandalized by what he saw as the inefficient, corrupt and cruel administration of British India' (Keighren 2017a, 71) and released harsh criticisms of British rule and repression under the auspices of the East India Company. While Macintosh could hardly be defined as a 'geographer', also because geography was not yet canonised as an academic discipline at that time, travel literature was then one of the main expressions of geographical knowledge. Moreover, John Murray was the mainstream publisher for the circulation of these travel accounts from the British Empire (Withers, Keighren and Bell 2015). In this light, Keighren notices that 'Murray's decision to publish a text so evidently critical of an organization in which he was both financially and socially embedded appears somewhat peculiar' (Keighren 2017a, 72).

\section{F. Ferretti, 2019, "Rediscovering other geographical traditions", Geography Compass, https://onlinelibrary.wiley.com/doi/full/10.1111/gec3.12421}


Although Keighren discusses this case from the angle of editorial issues and of the circulations and receptions of Macintosh's text, it is possible to argue that this is a further example of early mobilisation of geographical knowledge for serving political agendas other than those of the state, the empire or the army.

A further example of the different political agendas which can be mobilised in geography, eventually related to a same geographical object, is provided by a paper of Mike Heffernan and Ben Thorpe on the Tariff Walls Map produced by Sir Clive Morrison-Bell (1871-1956). This map was 'a three-dimensional model of Europe originally constructed in 1926, on which international borders were represented by actual physical walls, the varying heights of which reflected the average tariffs levied by each country upon imported goods' (Heffernan and Thorpe 2018,24). While the map was conceived by its creator, a Conservative politician, as a plea for free trade serving British interests within the League of Nations, the uses and reception of this geographical object went well beyond this authorial intentionality. While 'there is no evidence that Morrison-Bell was influenced by European geopolitical cartography, or by professional geographers more generally' (Heffernan and Thorpe 2018, 30), it is possible to appreciate the performativity of this map in its subsequent readings, fostered by its exposition in heterogeneous places including the 1927 International Labour Conference in Geneva. Eventually, after the 1929 Big Crisis, 'the TWM was recast first as a rallying cry for European unity and then, much to Morrison Bell's astonishment, as evidence to support the case for protectionism rather than free trade and eventually for the revision of the international border devised at Versailles' (Heffernan and Thorpe 2018, 36). Other works by Heffernan address unorthodox figures like Sándor Radó (1899-1981), a Hungarian cartographer and Soviet spy, whose adventurous life shows once more that geography is not an innocent science and can serve complex political agendas (Heffernan 2015; Györi 2015). The fact that geographical works can have diverse political uses beyond the intentionality of their authors allows considering research on circulations of knowledge and reception studies as a crucial exercise to assess the plurality and complexity of geographical traditions.

\subsection{Reengaging with feminist historical geographies}

In the past three decades or so, some of the most vibrant contributions to critical geographies and their histories have come from feminist scholars. While the idea of feminist historical geographies has been refreshed by initiatives including the special number of Historical Geography edited by Tamar Rothenberg, Karen Morin and Mona Domosh (2016), a recent section of The Professional Geographer, edited by Heike Jöns, Janice Monk, and Keighren, discusses issues of inclusion within histories of geographical knowledge with a special focus on female agencies. Debates on the suppression of women's voices from geography and the related discussion on how to avoid gender essentialism have been very rich and go beyond the scope of this text (see for an account: Maddrell 2009). Yet, I would argue that what is new in this focus section is that its authors raise a problematic similar to what I am discussing here, that is the need for enlarging the reach of the philosophy and history of geography by including a new "variety of previously hidden, unfamiliar, and mundane aspects of its creation and dissemination' (Jöns, Monk and Keighren 2017, 656). This implies 'identifying and exploring diverse archives that more fully capture the contributions made by those heretofore wrongly ignored in geography's histories' (Jöns, Monk and Keighren 2017, 659). This eventually includes interrogating the places where geography was produced to understand the reasons for overlooking certain figures and certain ways of producing geographical knowledge. For

\section{F. Ferretti, 2019, "Rediscovering other geographical traditions", Geography Compass, https://onlinelibrary.wiley.com/doi/full/10.1111/gec3.12421}


instance, a 'relative absence from conference networking presents a specific reason for the long invisibility of women in geography and other disciplines despite often substantial writings' (Jöns, Monk and Keighren 2017, 657). Crucially, the authors stress the importance of these historical enquiries for addressing present-day agendas, by noticing that 'the systematic underrecognition of women's contributions to academic knowledge production ... is still a frequent practice in twenty-first-century academia' (Jöns, Monk and Keighren 2017, 657).

Among the contributions to this section, Jöns's paper analyses 'the role of women in the transformation of the University of Cambridge from an ancient centre of learning, ... into a modern research university, sustained since the 1920 s by an increasingly mobile academic workforce' (Jöns 2017, 671). Even though this paper refers to a prestigious European university, canonized as a place to produce scholarly geography, the author significantly claims that 'feminist historical geography and feminist historiography of geography' (Jöns 2017, 679) can enlarge current notions of geography and foster interdisciplinary engagement. Keighren's paper on the contrasted process of women's inclusion in the Royal Geographical Society extends former literature on this process by analysing the little-known case of the Geographical Circle of the Lyceum Club based on newspaper sources, given the paucity of other kinds of documents. This already highlights the problem 'that historians of geography work with fragments and slivers, more often than they do with satisfying wholes' (Keighren 2017b, 662), questioning the influence that institutional archives have played in informing 'canonical' histories of geography. Again, this case confirms the political complexity of geography: although the inclusion of women in geographical societies is universally considered as a progressive endeavour, the Circle was an overtly imperialist group and its leader Bessie PullenBurry was right-wing, coming to embrace 'fascist politics' (Keighren 2017b, 665). This situation also stimulates reflections on the fact that engaged scholarship and explicit political commitment do not necessarily correspond: a reactionary person could have been a campaigner for women rights in geography, prompting civil liberties which went well beyond that specific situation.

In addition to the recovery of disciplinary histories which can be deemed 'other' from a gendered standpoint, there is increasing recognition of intersectional ideas in scholarship investigating histories of insubordination by women challenging different forms of domination. In the history of geography, exclusions have also been motivated by diverse arrays of political, epistemological, racial, cultural, gender or linguistic biases. This constitutes a further argument for making plural and heterogenous responses to these exclusions, to be performed both through the inclusion of different actors in geographical scholarship and through the enlargement of disciplinary paradigms. In the field of cultural and historical geographies, key contributions by Caroline Bressey discuss women's anti-racist engagement in Victorian Britain analysing the alternative geographical imaginations spread by the journal Anti-Caste (Bressey 2013). This research stands at the intersection between geography and radical histories in recovering black women's lives and questioning racial biases in schools' historical curricula (Bressey 2017). Likewise, interdisciplinary literature sensitive to geography and spatial issues is rediscovering anti-imperial views from women such as Ida Wells-Burnett or more recently Gloria Anzaldúa (Marso 2016). Black feminisms are gaining increasing importance in inspiring initiatives on the 'colonial present' of the discipline in RGS-IBG research groups like the RACE (Noxolo 2017), comprising scholars interested in geography's pasts. Concurrently, there seems to be a renewed interest for the intersection of geography and Afro-American

\section{F. Ferretti, 2019, "Rediscovering other geographical traditions", Geography Compass, https://onlinelibrary.wiley.com/doi/full/10.1111/gec3.12421}


histories, as exemplified by recent returns on William Bunge's Fitzgerald through the lenses of critical race studies (Bentley et al., 2016). Yet, one can argue that, despite some openings, historical geographers (including the author of this paper) should deal more with this kind of 'other' stories.

\subsection{Discovering early counter-mappings}

Further rediscoveries of early alternative or 'subversive' social uses of geographical knowledge, eventually under the form of maps, are ongoing in the history of cartography. While one of the inspirers of this field of studies, John Brian Harley, had argued that maps are essentially the instrument of power, and hardly that of social or political subversion, because maps' 'ideological arrows have tended to fly largely in one direction, from the powerful to the weaker in society' (Harley 2001, 79), his continuators are now reconsidering different uses of maps. The recent collective book Decolonizing the Map, edited by James R. Akerman, the former editor of The Imperial Map (Akerman 2009), is presented as 'an obvious counterpoint and successor [of the former book, addressing] the engagement of mapping in the long and clearly unfinished process of decolonisation and the parallel process of nation building from the late eighteenth century to the mid-twentieth century' (Akerman 2017, i).

While the cartographic invention of newly decolonised nation states can be considered part of the exercise of formal political power, the construction of alternative models for representing the nation during anti-colonial struggles can be conversely considered as a form of countermapping. Although it is not possible to establish a rigid distinction between these two typologies, one can consider mappings as ways to 'put the historical experiences and processes of decolonisation in Africa and Asia, in North America and Latin America, in Oceania and Southwest Asia into conversation, comparison and relation to one another' (Craib 2017, 13). For Raymond Craib, cartographic devices like toponyms and borders, including artistic features of maps, were tools of mobilisation for challenging both 'internal' and 'external' colonialisms, from the decolonisation periods until current claims of indigenous peoples, including 'revolutionary' uses of surveys to counter latifundia during 1910-1920 'Mexico's revolution' (Craib 2017, 45). Several cases of indigenous agency and complex negotiations in colonial mappings and maps' uses in decolonisation are likewise discussed in this book for cases such as Colombia (Castillo 2017), Egypt (Culcasi 2017) and India (Ramaswamy 2017). Other studies in the history of cartography highlighted how mappings were crucial in the controversies between South American decolonised states and European colonial powers, like in the case of the 1897-1900 French-Brazilian border dispute over Guiana, eventually won by Brazil (Ferretti 2015). Therefore, de-colonial mappings, counter-mappings and complex agencies within the production of colonial maps can be considered as part of other geographical traditions, and further work is needed in this direction.

\section{Historicising the critical turn (1960-1970s) between North and South}

The protagonists of the critical and radical turn which occurred in geography in the 1960s and 1970s around journals like Antipode are being canonised as major figures in the history of geography (Cresswell 2013). This growing historiographical attention to a relatively recent period in disciplinary histories can be likewise considered as a reassessment of disciplinary traditions. In this vein, authors like Trevor Barnes question the divide between a 'conservative' spatial revolution characterising those decades and a 'radical' reaction to this, showing how these phenomena were strictly interconnected, through figures like David Harvey or William

\section{F. Ferretti, 2019, "Rediscovering other geographical traditions", Geography Compass, https://onlinelibrary.wiley.com/doi/full/10.1111/gec3.12421}


Bunge (Barnes 2009 and 2017). It is possible to read in this light contributions like the recent publication of the archives of the Union of Socialist Geographers Newsletter by the Antipode Foundation, ${ }^{2}$ the publications dedicated to reassessing Neil Smith's works (Heynen et al. 2017; Mitchell 2014 and 2015), and numerous studies on William Bunge (Bergmann and Morrill 2018; Barnes 2016; Barnes et al. 2011; Heynen 2013). Research on new archives is likewise highlighting the relations between radical approaches and exponents of research lines traditionally considered as less 'subversive', like humanistic geographies (Cresswell 2013): it is the case with Anne Buttimer (1938-2017) and her worldwide networking with geographers, including many international radical exponents (Ferretti and Jones 2018). This context confirms how complicated the establishment of 'canons' in geography is (Keighren, Abrahamsson and Della Dora 2012) and how many possibilities historical geographers have for dealing with non-academic experiences in the production of engaged geographical knowledge. This is further demonstrated by Jo Norcup's thesis on the British non-academic journal Contemporary Issues in Geography and Education (Norcup 2015). Thus, it is possible to argue that the progressive historicising of relatively 'recent' periods in the history of geography is progressively highlighting the breadth and pervasive nature of critical and radical tendencies in the discipline.

Crucially, critical geographical traditions from the Global South play a central role in this historicising of radical approaches in the 1960s and 1970s. Many of the authors concerned are Brazilian, like Milton Santos (1926-2001), the radical geographer who was exiled after the 1964 military coup in his country. Permitted to return only in 1977, Santos was protagonist of an influential networking with the initiators of early Northern radical geographies in France and in the United States (Davies, 2018; Melgaço 2018, Melgaço and Prouse 2017, Ferretti and Viotto 2018, Vasconcelos 2018). Santos's work is also the subject of a critical forum published on the website of the Antipode foundation, ${ }^{3}$ and the Manifesto for an Active Geography that he consigned with his closest Brazilian collaborators has been recently translated, like his key book on Globalization (Santos 2017). Santos's rescue is largely the result of efforts in making his work know to Anglophone readerships, accomplished by scholars like Carolyn Prouse and Lucas Melgaço. It is possible, however, to argue that this is only the tip of the iceberg in the scholarly movement rediscovering this period and this kind of figures.

For instance, a Brazilian scholar whom Santos considered as his first teacher, Josué de Castro (1908-1973) is still an inspiration for intellectuals who explicitly rely on his political and intellectual legacy, such as Jean Ziegler (2013) and Jahi Chappell (2018). De Castro's works are the object of rediscovery for Brazilian historians, geographers and medical scholars (Fontana 2014; Santos Silva 2016) while, in English-speaking geographical scholarship, his name remains mostly unknown, albeit with some notable exceptions like Archie Davies's ongoing $\mathrm{PhD}$ research at King's College ${ }^{4}$ and a recent paper by Eric Carter on population control in Latin America (Carter 2018). Another exponent of this network of Brazilian geographers who fought against the military dictatorship was Manuel Correia de Andrade

\footnotetext{
2 Antipode Foundation, The Union of Socialist Geographers Newsletter, 1975-1983 https://antipodefoundation.org/2017/06/28/usg-newsletter-archive/

3 Antipode Foundation, Introducing Milton Santos https://antipodefoundation.org/2017/03/15/introducingmilton-santos-and-the-active-role-of-geography/

4 Archie Davies, Josué de Castro's Geografia Combatente and the political ecology of hunger, $\mathrm{PhD}$ thesis. Supervised by Alex Loftus and Jeff Garmany, Department of Geography, King's College London.
}

F. Ferretti, 2019, "Rediscovering other geographical traditions", Geography Compass, https://onlinelibrary.wiley.com/doi/full/10.1111/gec3.12421 
(1922-2007), whose archives are now interesting Brazilian and international scholars (Ferretti 2018b; Iumatti and Nicodemo 2018). A Mexican geographer and activist of the same generation as Santos, acquainted with the Brazilian scholars mentioned above, Angel Bassols Batalla (1925-2012), produced works which are likewise being reconsidered in contemporary Mexican scholarship. These authors present Batalla as an example for humanistic and engaged geographies (Delgadillo 2015) and as the advocate of a critical Southern geography supporting alternative views for enhancing endogenous development and national sovereignty against European and North American imperialisms (Mendoza Vargas 2017). Critical, reflective and epistemological approaches are now considered as a marker of Latin American geographies since the 1990s (Urquijo Torres and Bocco Verdinelli 2016).

These works are often inspired by the so-called 'biographical turn' in the history of geography (Baigent 2004), arguing for considering life experiences beyond mere texts to provide more contextual readings for the history of ideas. While these approaches can still give the impression that the history of geography is about 'Big Men', a certain emphasis on networks and circulations of knowledge can correct this perception in general terms. More specifically, what deserves more recognition is the strong female participation in these networks. Some important papers have already appeared in recent years, like an interview by Neil Smith and Caroline Desbiens with Graciela Uribe Ortega (1928-2000), an important dissident geographer who had to flee from Chile in 1973 to escape the repression of Pinochet's dictatorship (Mendoza Vargas 2018). There, Uribe claimed that: 'Although men maybe won't like to admit it, there are many women in Latin American geography, and we have existed for many years' (Smith and Desbiens 2000, 547). In the same vein, a report by Blanca Rebeca Ramirez Velazquez on the Latin American critical geographers' network GeoRaizAl discusses the links between feminism, de-coloniality and reconsideration of indigenous knowledges, highlighting the centrality of female agency in present-day networks (Ramirez Velazquez 2012). Finally, scholarship from the 'Global South' has great potentialities for nourishing different disciplinary histories, on the condition that geographical scholarship becomes truly cosmopolitan, international and available to consider multilingual sources and multicultural approaches to its problematics, as I explain in the following section.

\section{Recent trends from the South: reversing the colonial gaze}

One of the most brilliant examples of reversing the traditional European gaze from North to South is the rubric Nossos Clásicos (Our Classics) published in each number of Geographia (Rio de Janeiro), one of the most prestigious peer-reviewed Brazilian journals of geography. This series usually includes a text of a famous non-Brazilian geographer, translated into Portuguese for the first time and accompanied by an essay of a Brazilian scholar. Critical and anarchist geographies are well represented in this rubric, with texts by Kropotkin (Netto 2018, El Akim 2014), Henri Lefebvre (2017), and less recently Reclus (2010). In the rest of the journal, figures of critical geographies are often discussed, like in the case of recent recollections of Brazilian feminist geographers on Doreen Massey (Silva, Ornat and Chimin 2017). This also corresponds to new Brazilian and Latin American disciplinary trends paying more attention to international, and especially English-speaking, literature. Traditionally, scholarship in French has enjoyed a major prestige in the region, mainly due to Latin American scholars' wariness of North American cultural imperialism. While works on the French university missions in Brazil have shown that Francophone scholarship was not less imperialist than the Anglophone one (Ferretti 2014), it is worth noting that this led to the early translation

\section{F. Ferretti, 2019, "Rediscovering other geographical traditions", Geography Compass, https://onlinelibrary.wiley.com/doi/full/10.1111/gec3.12421}


and circulation in Spanish and Portuguese of French radical works such as books of Lefebvre, and of Yves Lacoste, from the 1970s (Machado 2008). In this section, I also discuss French contributions to OGTs showing that, ironically, Francophone scholarly literature can be compared today to the Latin American ones in terms of its peripheral position in relation to the Anglophone mainstream.

Today, Brazilian historians of geography are doing original archival work on 'Northern' sources, like in the case of Willian Antunes's doctoral work on Camille Vallaux (1870-1945). While no French thesis exists on the works of this original and 'dissident' French geographer, Brazilian scholarship is reconsidering this figure as an early representative of a social geography which is not unfamiliar with political engagement, a rather uncommon feature in 'classical' French geography (Antunes 2017). One of the best examples of 'reversing the gaze' are the works of Leonardo Arantes on German geography, namely the 'classics' of Humboldt and Carl Ritter (1779-1859). As for Reclus (who was, significantly, Ritter's student), these classic authors are often quoted but their original writings remain little-known. For Geographia, Arantes translated from German and commented on some texts of Humboldt and Ritter, aiming to demonstrate that they shared views of geography as a science for social progress. For Arantes, Ritter's text on geographical education demonstrates that the German geographer considered that one of the most important roles of geography is the formation of responsible citizens 'through the construction of a worldview by stimulating creative geographical imagination rather than using texts as mnemonic devices' (Arantes 2016b, 212).

Among Latin-American readings of early European geographies, a special place is reserved for Humboldt, whose empathetic commentaries on Amerindian cultures are the reason of his lasting reputation as one of the inspirers of Latin-American decolonisation and an early advocate of indigenous peoples (Buttimer 2013). According to Arantes, Humboldt's anticolonial critiques anticipated 'many aspects of the positions carried out by the theorists of the post- or de-coloniality' (Arantes 2016a, 165). In Humboldt's text, 'the idea of colony, that is pretending that a land is the tributary of another, is intrinsically immoral' (Arantes 2016a, 173). For Humboldt, the alleged freedom of people living in the colonies only meant 'being allowed to mistreat [black] slaves with impunity and to insult white people if they are poor' (Arantes 2016a, 174). Thus, this position also implied a critique of slavery and of social inequality in general. Humboldt's anti-racist and anti-slavery commitment is especially apparent in the texts translated by Arantes: mistreatment of Blacks was defined as 'a horror of [Caribbean] islands' (Arantes 2016a, 174). Following in the line of Humboldt's appraisals, Héctor Mendoza Vargas (2016) compares the journey of three eminent German travellers to Mexico in different periods of the history of geography: Humboldt, Friedrich Ratzel (1844-1904) and Adolf Reichwein (1898-1944). In this 'German gaze', imperial implications of both Germany and the United States are explicitly examined by Mendoza, stressing the changes in German culture through the lens of these geographers' approaches to Mexico, that is inverting again the classical direction of the gaze.

In Brazil, 'Northern' influences have been effective in the establishment of academic geography especially by way of the French university missions, that were instrumental in the foundation of the first Brazilian research universities in the 1930s. Now, Brazilian scholars have begun to question the directionality of this cultural transfer, showing their awareness of cultural imperialism. In this vein, an important collection of essays by leading French

\section{F. Ferretti, 2019, "Rediscovering other geographical traditions", Geography Compass, https://onlinelibrary.wiley.com/doi/full/10.1111/gec3.12421}


'classical' geographer Paul Vidal de la Blache (1845-1918) has been edited by Sérgio Nunes, Guilherme Ribeiro and Rogério Haesbaert (Haesbaert, Pereira and Ribeiro 2012). A pioneering work by José Borzacchiello da Silva on the history of French-Brazilian exchanges in geography, first published in Brazil in 2012, has been recently translated into English and contains explicit interrogations on the colonising intentions of the components of French university missions (Borzacchiello 2016). Another research monograph by geographer Guilherme Ribeiro on the work of famous French historian Fernand Braudel (1902-1985) marks a Brazilian re-appropriation of the idea of 'geo-history', formerly a sort of 'privilege' for French scholarship (Ribeiro 2017).

The leading Brazilian journal in historical geography and in the history and philosophy of geography, Terra Brasilis, regularly publishes papers on the works of 'Northern' scholars, with an emphasis on critical and anarchist traditions in geography, which was also locally implemented through events like the international conference on Elisée Reclus organised at the USP in 2011 (Ramirez Palacios and Skoda 2016). Terra Brasilis is publishing a dossier series on 'Geographers' Trajectories' where the idea of looking from the South at leading international figures in geography is apparent. The journal Territôrio Autónomo likewise publishes contributions inspired by the anarchist tradition, eventually represented by ideas of Reclus and Kropotkin reinterpreted through the lenses of more recent authors such as Murray Bookchin (1921-2006) and Cornelius Castoriadis (1922-1997). In this vein, leading Brazilian critical geographer Marcelo Lopes de Souza has recently published a book on anarchism and geography, where attention is also paid to the historical aspects of this relation (Souza 2017).

In the French-Brazilian journal Confins, Breno Viotto Pedrosa examines the relation between Carl Sauer and Alfred Kroeber over superorganicism and ideas on cultural geography. Pedrosa argues that, after that cultural approaches exerted an increasing influence on Brazilian geography from the 1990s, it is time that Brazilian scholars investigate closely the origins of this cross-contamination to 'understand the origins of cultural geography at all' (Viotto Pedrosa 2017) performing original research on European and North American sources. Again, this means inverting the classical direction of scholarly views and visions from North-South to South-North directions.

It is worth concluding by mentioning Francophone scholarship. Albeit not exactly representing the South, and despite the survival of some debris of the French imperial past like the conservation of French as an official language for the IGU, French scholarship is relatively marginalized in relation to mainstream geography journals. Nevertheless, research on early anarchist geographers has its specific French strands, especially represented by works on Reclus by authors such as Ronald Creagh, Philippe Pelletier, Isabelle Lefort and Christophe Brun (Creagh and Deschler 2018; Lefort and Pelletier 2015; Brun 2015). In French-speaking Switzerland, the Geneva publishing house Héros-limite recently published several anthological books with work by Elie and Elisée Reclus, Charles Perron, Kropotkin and other early anarchist geographers. These Francophone publications generally match international tendencies in the rediscovery of early anarchist geographies by engaging with new archives and original texts. In the same vein, after dealing a lot with works of Vidal de la Blache's academic successors, French historians of geography are increasingly considering authors who were marginalized for different reasons from the academic mainstream and had often to make their careers in other fields like politics, diplomacy and publishing. They are defined as géographes-hors-les-murs

\section{F. Ferretti, 2019, "Rediscovering other geographical traditions", Geography Compass, https://onlinelibrary.wiley.com/doi/full/10.1111/gec3.12421}


(geographers outside the walls) (Clerc and Robic 2015), and some of them also took dissident and anti-colonialist positions, like in the case of Yves Châtaigneau (Clout 2016).

\section{Conclusion}

It is possible to conclude that geography's pasts show how geography was not only a science of the empire, but also a science for diverse and/or unorthodox thinking. Scholarship is increasingly rescuing works and concepts that were formerly erased from the history of geography for the political, geographical, linguistic, cultural or professional positionalities of their authors. In this vein, research on new sources and original texts through multilingual and critical approaches is the key characteristic of what I call the rediscovery of OGTs. This paper has shown that the study of these alternative traditions is more vital, cosmopolitan, international and multilingual than ever. It enlarges geography's disciplinary boundaries by advocating geographers' consideration for geographical knowledge which did not carry the explicit label of 'geography', or which was produced in places or contexts that were overlooked, underplayed or marginalised by the dominant canons of the discipline. Likewise, it questions the very idea of having dominant canons or paradigms in geography, promoting a plural, open and inclusive discipline.

I would also argue that rediscovering OGTs is not only of interest for the fields of the history of geography and historical geography to avoid overlooking key currents of thoughts. It also proves that looking backwards is more and more necessary to understand what is going on today. While Clarence Glacken famously argued that the history of scholarly disciplines is indispensable to avoid the arrogance of believing that we have invented everything (Glacken 1980), OGTs are not only challenging commonplaces on disciplinary tradition. They are also confirming that geography was a science attracting various kinds of subversive, progressive and unorthodox authors: therefore, it embeds in its paths values of cosmopolitanism, pluralism and difference, allowing critical geographers to be sometimes proud, and not only ashamed, of their disciplinary tradition. This has outstanding repercussion on contemporary agendas: including in the discipline actors, places, languages and practices which were formerly marginalised, OGTs can decisively contribute to the task of decolonising geography and of rendering it more open to differences, as often solicited in the last years (Radcliffe 2017; Esson et al. 2017).

However, this line of research is not exempted from limitations and contradictions: the looseness of the possible definitions of OGTs can be criticised, even though I would argue that this should serve as a device for fostering inclusiveness and open-mindedness in the geographical field. Finally, positing the issue of monolingualism implies likewise limitations: for instance, in this paper I could not address scholarly literature in languages which stand outside my linguistic skillset, such as Hindi, Mandarin, Vietnamese and so on. This calls for further collaborative efforts in the internationalisation of this field of study.

\section{References}

Adams, M.S. (2015). Kropotkin, Read and the intellectual history of British anarchism. London: Palgrave MacMillan.

Akerman, J. (Ed.) (2009). The imperial map, cartography and the mastery of empire. Chicago: University of Chicago Press.

F. Ferretti, 2019, "Rediscovering other geographical traditions", Geography Compass, https://onlinelibrary.wiley.com/doi/full/10.1111/gec3.12421 
Akerman, J. (ed.) (2017). Decolonizing the map: cartography from colony to nation. Chicago: University of Chicago Press.

Antunes, W. (2017). Um model de resenha por Camille Vallaux. Geographia, 19(39), 95-102. Arantes, L. (2016). Carl Ritter: educador e geógrafo, Geographia, 18(36), 207-212

Arantes, L. (2016). Alexander von Humboldt. Geographia 18(38), 164-176

Baigent, E. (2004). The geography of biography, the biography of geography: rewriting the Dictionary of National Biography. Journal of Historical Geography, 30, 531-551.

Bantman, C., \& Altena, B. (Eds.) (2015). Reassessing the Transnational Turn: scales of analysis in anarchist and syndicalist studies. New York and London: Routledge

Barnes, T.J. (2009). Not only ... but also': Quantitative and critical geography. The Professional Geographer 61(3):292-300.

Barnes, T.J. (2016). The odd couple: Richard Hartshorne and William Bunge. The Canadian Geographer/Le Géographe canadien, 60(4), 458-465.

Barnes, T.J._(2017). A marginal man and his central contributions: The creative spaces of William ('Wild Bill') Bunge and American geography, Environment and Planning A, Online First https://doi.org/10.1177/0308518X17707524

Barnes, T.J., Heynen, N., Merrifield, A. and Mountz, A. (2011). Classics in human geography revisited: William Bunge's (1971) Fitzgerald: Geography of a revolution. Progress in Human Geography, 35(3), 712-20.

Bentley, G.C., McCutcheon, P., Cromley, R.G. and Hanink D.M. (2016). Fitzgerald: A return to the neighbourhood and its contemporary structural and geographical contexts. The Professional Geographer, 68(3), 414-426.

Bergmann, L. and Morrill, R. (2018). William Wheeler Bunge: Radical geographer (19282013). Annals of the American Association of Geographers, 108(1), 291-300.

Borzacchiello da Silva, J. (2016). French-Brazilian geography: the influence of French geography in Brazil. Berlin: Springer.

Bressey, C. (2013). Empire, race and the politics of anti-caste. London: Bloomsbury.

Bressey, C. (2017). Radical History then and now. History Workshop Journal, 83, 217-222

Brun, C. (2015) Elisée Reclus, une chronologie familiale. Raforum Reclus http://raforum.info/reclus/spip.php?article455

Buttimer, A. (2012). Alexander von Humboldt and planet earth's green mantle. Cybergeo, http://journals.openedition.org/cybergeo/25478

Castillo, L. (2017). Cartography in the production (and silencing) of Colombian independence history, 1807-1827. In J. Akerman (Dd.). Decolonizing the map: Cartography from colony to nation. Chicago: University of Chicago Press, 110-159.

Chappell, J. (2018). Beginning to End Hunger. Food and the Environment in Belo Horizonte, Brazil, and Beyond. Oakland: University of California Press.

Clerc, P. \& Robic, M.C. (Eds.) (2015). Des géographes hors-les-murs? Itinéraires dans un monde en mouvement, 1900-1940. Paris: L'Harmattan.

Clout, H. (2016). The Vidalian Geographie universelle: Five authors on the fringes of the French university world -Yves Chataigneau (1891-1969), Pierre Denis (1883-1951), Fernand Grenard (1866-1942), Fernand Maurette (1878-1937), and Paul Privat-Deschanel (18671942). In: H. Lorimer and C.W.J. Withers (Eds). Geographers: Biobibliographical Studies 35. London: Bloomsbury Academic, 63-93.

Craggs, R. \& Wintle, C. (Eds.) (2016). Cultures of decolonisation, transnational productions and practices, 1945-70. Manchester: Manchester University Press.

F. Ferretti, 2019, "Rediscovering other geographical traditions", Geography Compass, https://onlinelibrary.wiley.com/doi/full/10.1111/gec3.12421 
Craib, R. (2017). Cartography and decolonisation. In J. Akerman (Ed.). Decolonizing the map: Cartography from colony to nation. Chicago: University of Chicago Press, 11-71.

Creagh, R. and Deschler, C. (Eds) (2018) [E. Reclus] Lettres à Clarisse. Paris: Garnier.

Cresswell, T. (2013). Geographic Thought: A Critical Introduction. Chichester: WileyBlackwell.

Culcasi, K. (2017). Multi-scalar nations: Cartography and counter-cartography of the Egyptian nation-state. In J. Akerman (Ed.). Decolonizing the map: Cartography from colony to nation. Chicago: University of Chicago Press, 252-283.

Davies, Andy (2017). Exile in the homeland? Anti-colonialism, subaltern geographies and the politics of friendship in early twentieth century Pondicherry, India. Environment and Planning D, Society and space 35(3). 457-474.

Davies, Archie (2018). Milton Santos: The conceptual geographer and the philosophy of technics. Progress in Human Geography, early view http://journals.sagepub.com/doi/full/10.1177/0309132517753809

Delgadillo, J. (2015). Por una geografía humanista: Ángel Bassols Batalla. Mexico: UNAM.

Driver, F. (2012). Hidden histories made visible? Reflections on a geographical exhibition. Transactions of the Institute of British Geographers, 38(3), 420-435.

El Hakim de Paula, A. (2014). Piotr Kropotkin-Apresentação 16(32), 171-173.

Esson, J., Noxolo, P., Baxter, R., Daley, P, Byron, M. (2017). The 2017 RGS-IBG chair's theme: decolonising geographical knowledges, or reproducing coloniality? Area 49(3), 384388.

Featherstone, D. (2017). Anti-colonialism and the contested spaces of communist internationalism. Socialist History, 52, 48-58.

Ferretti, F. (2015). A new map of the Franco-Brazilian border dispute (1900). Imago Mundi 67(2), 229-242

Ferretti, F. (2016). Arcangelo Ghisleri and the "right to barbarity": geography and anticolonialism in Italy in the Age of Empire (1875-1914). Antipode, 48(3), 563-583.

Ferretti, F. (2017). Political geographies, unfaithful translations and anti-colonialism: Ireland in Élisée Reclus's geography and biography'. Political Geography no. 59: 11-23

Ferretti, F (2018a). Anarchy and Geography. Reclus and Kropotkin in the UK. Abingdon: Routledge.

Ferretti, F. (2018b). Geographies of internationalism: radical development and critical geopolitics from the Northeast of Brazil. Political Geography, 63, 10-19.

Ferretti, F., Barrera de la Torre, G. Ince, A., Toro F. (Eds.) (2017). Historical Geographies of Anarchism. Abingdon: Routledge.

Ferretti, F \& Viotto Pedrosa, B. (2018), Inventing critical development: a Brazilian geographer and his Northern networks. Transactions of the Institute of the British Geographers, 43(4), 703-717.

Ferretti, F \& Jones, A (2018). Anne Buttimer. 1938-2017. Geographers. Biobibliographical Studies, 37, 13-40.

Fontana, C. 2014. Fome e questão ambiental: uma leitura a partir da obra de Josué de Castro (PhD Dissertation). Porto Alegre: UFRGS.

Glacken, C. (1980). Interview to Clarence Glacken realised by Allan Pred. International Dialogue Project, G15, https://www.youtube.com/watch?v=izZ2mbXsw94\&feature=youtu.be Griffin, P. (2018). Making usable pasts: collaboration, labour and activism in the archive. Area, 40 (4), 501-508.

F. Ferretti, 2019, "Rediscovering other geographical traditions", Geography Compass, https://onlinelibrary.wiley.com/doi/full/10.1111/gec3.12421 
Györi, R. (2015), Communist geography instead of nationalist geography: The new cadres and the case of Sándor Radó. Hungarian Cultural Studies, 8, 124-146.

Haesbaert, R., Nunes Pereira, S., Ribeiro G. (Eds.) (2012). Vidal, Vidais: textos de Geografia Humana, Regional e Política. Rio de Janeiro: Bertrand Brasil.

Heffernan, M. (2015) The interrogation of Sándor Radó: Geography, communism and espionage between World War Two and the Cold War. Journal of Historical Geography, 47, $74-88$.

Heffernan M, Thorpe, B.J. (2018). The map that would save Europe': Clive Morrison-Bell, the Tariff Walls Map, and the politics of cartographic display. Journal of Historical Geography, 24-40.

Heynen, N. (2013). Marginalia of a revolution: naming popular ethnography through William W. Bunge's Fitzgerald. Social and Cultural Geography, 14(7), 744-751.

Heynen, N, Kent, A, McKittrick K, Gidwani, V, Larner, W (2017). Neil Smith's long revolutionary imperative. Antipode, 49(1), 5-18.

Hodder, J. (2016). Toward a geography of Black Internationalism: Bayard Rustin, nonviolence and the promise of Africa. Annals of the American Association of Geographers, 106(6), 13601377

Iumatti, P.T \& Nicodemo, T.L. 2018. Arquivos pessoais e a escrita da história no Brasil: um balanço crítico. Revista Brasileira de História, 38(78), 1-24.

Jöns, H. (2017). Feminizing the University: The Mobilities, Careers, and Contributions of Early Female Academics in the University of Cambridge, 1926-1955. The Professional Geographer, 69(4), 670-682.

Jöns, H., Monk, J., Keighren, I.M. (2017). Introduction: toward more inclusive and comparative perspectives in the histories of geographical knowledge. The Professional Geographer, 69(4), 655-660.

Kearns, G. (2004). The Political Pivot of Geography. The Geographical Journal, 170, 337346.

Keighren, I.M. (2017a). Circulating seditious knowledge: the 'daring absurdities, studied misrepresentations, and abominable falsehoods' of William Macintosh. In H. Jöns; P. Meusburger, M. Heffernan. Mobilities of knowledge. Cham: Springer, 67-84.

Keighren, I.M. (2017b). 'A Royal Geographical Society for ladies': The Lyceum Club and women's geographical frontiers in Edwardian London. The Professional Geographer, 69(4), 661-669.

Keighren, I.M. (2018). History and philosophy of geography II: The excluded, the evil, and the anarchic. Progress in Human Geography, 42(5), 770-778.

Keighren, I.M., Abrahamsson, C., Della Dora, V. (2012). On canonical geographies. Dialogues in Human Geography, 2(3), 296-312.

Keighren, I.M., Withers, C.W.J., Bell B. (2015). Travels into print: Exploration, writing, and publishing with John Murray, 1773-1859. Chicago: Chicago University Press.

Kinna, R. (2016). Kropotkin: Reviewing the Classical Anarchist Tradition. Edinburgh: Edinburgh University Press.

Lefort, I \& Pelletier, P. (2015). Élisée Reclus ou la condition géographique: habiter la terre. Annales de géographie 704(4), 338-350.

Lefebvre, H. (2017). Problemas teóricos da autogestão. Geographia, 19(41), 135-141.

Livingstone, D.N. (2012). Changing climate, human evolution, and the revival of environmental determinism. Bulletin of History of Medicine, 86(4), 564-95.

F. Ferretti, 2019, "Rediscovering other geographical traditions", Geography Compass, https://onlinelibrary.wiley.com/doi/full/10.1111/gec3.12421 
McGregor, J. (2017). Locating exile: decolonization, anti-imperial spaces and Zimbabwean students in Britain, 1965-1980'. Journal of Historical Geography, 57, 62-75.

Machado, C.R.S. (2008). Momentos da obra de Henri Lefebvre: uma apresentação. Ambiente e Alimentação, 13, 83-95.

MacLaughlin, J. (2016). Kropotkin and the Anarchist Intellectual Tradition. London: Pluto Press.

Maddrell, A. (2009). Complex Locations: Women's Geographical Work in the UK 1850-1970. Oxford: Wiley-Blackwell.

Marso, J.L. (2016) (ed.). Fifty-one feminist thinkers. Abingdon: Routledge.

Melgaço, L. (2017) Thinking outside the bubble of the Global North: introducing Milton Santos and 'the active role of geography'. Antipode 49(4), 946-951.

Melgaço, L. \& Prouse, C (Eds.) (2017). Milton Santos: Pioneer in geography. London: Springer.

Mendoza Vargas, H. (2016). La mirada alemana sobre México en tres viajeros: Alexander von Humboldt (1769-1859), Friedrich Ratzel (1844-1904) y Adolf Reichwein (1898-1944). Scripta Nova, 20, 544, http://revistes.ub.edu/index.php/ScriptaNova/article/view/544/19717

Mendoza Vargas, H. (2017). Ángel Bassols Batalla y la renovación de la geografía mexicana. Terra Brasilis, 9, http://journals.openedition.org/terrabrasilis/2307

Mendoza Vargas, H. (2018). Graciela Uribe Ortega y la transición de la geografía Mexicana. Terra Brasilis, 10, https://journals.openedition.org/terrabrasilis/2577

Merrifield, A. (1995) Situated knowledge trough exploration: reflections on Bunge's geographical expeditions. Antipode, 27(1), 49-70.

Mitchell, D. (2014). Neil Smith, 1954-2012: Marx ist geographer. Annals of the Association of American Geographers, 104(1), 215-222.

Mitchell, D (2015). Neil Smith (1954-2012). In Lorimer H. and Withers C.W.J. (Eds.). Geographers Biobibliographical Studies 34. London: Bloomsbury Academic, 203-244.

Netto R.J. (2018). Piotr Kropotkin: breve introdução ao autor. Geographia, 20(42), 115.

Norcup, J. (2015). Awkward geographies? An historical and cultural geography of the journal Contemporary Issues in Geography and Education (CIGE) (1983- 1991). PhD thesis, University of Glasgow.

Noxolo, P. (2017). Introduction: decolonising geographical knowledge in a colonised and recolonising postcolonial world. Area, 49(3), 317-319.

Pelletier, P. (2013). Géographie et anarchie: Reclus, Kropotkine, Metchnikoff. Paris: Editions du Monde Libertaire.

Radcliffe, S. (2017). Decolonising geographical knowledges. Transactions of the Institute of British Geographers, 42, 3, 329-333.

Ramírez Palacios, D. \& Skoda, A. (2016). Élisée Reclus e a Geografia dos Novos Mundos. Terra Brasilis, 7, http://journals.openedition.org/terrabrasilis/1761

Ramírez Velázquez, B.R. (2012). Geografía crítica: territorialidad, espacio y poder en América Latina. Investigaciones Geograficas, 77, 151-155.

Ramsawami, S. (2017). Art on the line: Cartography and creativity in a divided world. In J. Akerman (Ed.). Decolonizing the map: Cartography from colony to nation. Chicago: University of Chicago Press, 284-338.

Reclus, E. (2010). Crônica geográfica. Geographia, 12(24), 166-168.

Ribeiro, G. (2017). Fernand Braudel, geo-história e longa duração. Criticas e virtudes de um projeto historiográfico. São Paulo: Annablume.

F. Ferretti, 2019, "Rediscovering other geographical traditions", Geography Compass, https://onlinelibrary.wiley.com/doi/full/10.1111/gec3.12421 
Rothenberg, T., Morin, K.M., Domosh, M. (2016). Introduction: feminist historical geographies. Historical Geographies, 44, 27-29.

Santos M. (2017). Toward another Globalization: From the single thought to universal Conscience. Berlin: Springer.

Santos Silva, M.F. 2016. Josué de Castro: um Autor do Legado Esquecido? (PhD Dissertation). Campinas: Unicamp.

Sidaway, J.D., White, R.J., Barrera de la Torre, G., Ferretti, G., Crane, N.G., Loong, S., Knopp, L., Mott, C., Rouhani, F., Smith, J.M., Springer, S. (2017). Book review fora: The Anarchist Roots of Geography: Toward Spatial Emancipation. AAG Review of Books, 5(4), 281-296.

Silvia, J.M., Ornat, M.J., Chimin, A.B. (2017). Não me chame de senhora, eu sou feminista! Posicionalidade e reflexibilidade na produção geográfica de Doreen Massey. Geographia, 19(40), 11-20.

Siegrist, P. (2017). Historicising anarchist geographies: six issues for debate from a historian's point of view'. In F. Ferretti, G. Barrera, A. Ince, F. Toro (Eds.). Historical Geographies of Anarchism. Abingdon: Routledge, 129-150.

Smith, N., Desbiens, C. (2000). An Interview with Graciela Uribe Ortega. Environment and Planning D: Society and Space, 18(5), 545-556.

Souza, M.L. (2017). Por uma geografia libertaria. Rio de Janeiro: Consequência.

Souza, M.L., White, R.J. Springer, S. (Eds.) (2016). Theories of Resistance: Anarchism, Geography and the Spirit of Revolt. Lanham: Rowman \& Littlefield.

Sparke, M. (2007). Everywhere but always somewhere: critical geographies of the Global South. The Global South, 1-2, 117-126.

Springer, S. (2016). The Anarchist Roots of Geography: Toward Spatial Emancipation. Minneapolis: University of Minnesota Press.

Springer, S., Souza, M.L., White, R.J. (Eds) (2016). The radicalization of pedagogy: anarchism, geography, and the spirit of revolt. London: Rowan and Littlefield.

Stoddart D.R. (1975). Kropotkin, Reclus, and 'Relevant' Geography. Area, 7(3), 188-190.

Urquijo Torres, P and Bocco Verdinelli, G. (2016). Pensamiento geográfico en América Latina: retrospectiva y balances generales. Investigaciones Geográficas, 90, 155-175.

Vasconcelos, P.A. (2018). Milton Almeida dos Santos (1926-2001). In Baigent, E., \& Reyes Novaes A (Eds.). Geographers Biobibliographical Studies 37. London: Bloomsbury, 41-68.

Venuti, L. (Ed.) (2000). The translation studies reader. New York and London: Routledge.

Viotto Pedrosa, B. (2015). Sauer, Boas, Kroeber e a cultura superorgânica: notas sobre a

$\begin{array}{llll}\text { relação entre geografia antropologia. Confins, } & 23\end{array}$

http://journals.openedition.org/confins/9958

White, R.J. (2015). Following in the footsteps of Elisée Reclus: disturbing places of interspecies violence that are hidden in plain sight. In A.J. Nocella II, R.J. White and E. Cudworth (Eds.). Anarchism and animal liberation. Essays on complementary elements of Total Liberation. Jefferson: Mc Farland \& Company, 212-230.

White, R.J., Souza, M.L., Springer, S. (Eds) (2016). The Practice of Freedom: Anarchism, Geography, and the Spirit of Revolt. London: Rowan and Littlefield.

Ziegler, J. (2013). Betting on hunger. Why the world still goes hungry. New York/London: The New Press.

F. Ferretti, 2019, "Rediscovering other geographical traditions", Geography Compass, https://onlinelibrary.wiley.com/doi/full/10.1111/gec3.12421 